\title{
Microbial flora of the external os of the premenopausal cervix
}

\author{
LOUIS KEITH, DOUGLAS ENGLAND, FREDRICK BARTIZAL, ERIC BROWN, AND \\ CHARLES FIELDS
}

Departments of Microbiology and of Obstetrics and Gynecology, Chicago Medical School, University of Health Sciences, Chicago, Ill., 60612

The Lactobacillus (Doderlein's bacillus) (Wilson and Miles, 1964) had been regarded as the preponderant micro-organism in the vagina, at least after puberty. During the 1960 s a re-examination of the microbiology of the vagina was prompted by the widespread use of potent antibacterial agents and of oral contraceptives (Krupp and St. Romain, 1960; Morris and Morris, 1967; Morris, 1969). During the same period, minimal information appeared regarding the microbial flora of the cervix (Likar and Mrsevic, 1967; Chiang, Alexander, Wei, and Fresh, 1968; Galinski, Mierzejewski, and Emerich, 1969).

The present paper is a report on the microorganisms observed during a study of the external os of the cervix in a group of premenopausal women.

\section{Material and methods \\ PATIENTS}

Eighty patients were examined in June to August, 1970, in the Prenatal, Gynecology, and Family Planning Clinics at Mount Sinai Hospital, Chicago. The two criteria for inclusion in the investigation were the presence of the patients in the clinic during the study period and her premenopausal status.

Of the eighty women in the study, 75 were coloured and all were of a low socioeconomic class.

\section{MICROBIAL CULTURES}

A single trained examiner took triplicate swabs from the external os of the cervix through a sterile speculum. One swab was used to make a direct smear on a glass slide; the remaining two swabs were placed in modified Stuart's Transport Medium (Culturette, Scientific Products) and inoculated into appropriate culture media within 2 hours of sampling.

One culturette from each patient was used to inoculate the following media:

(a) Serratia Media (Goldin, Shaffer, and Brown, 1969);

(b) Mannitol Salt Agar (Difco) with $250 \mu \mathrm{g} . / \mathrm{ml}$. amphotericin B (Fungizone-GIBCO);

(c) Eosin-Methylene Blue (Difco);

(d) Sabouraud Dextrose Agar (Difco) with 200 units penicillin $\mathrm{G}$ and $0.05 \mathrm{mg}$. tetracycline $/ \mathrm{ml}$;

(e) Final inoculation in Micro Inoculum Broth (Difco)

Received for publication July 13, 1971 with $250 \mu \mathrm{g} . / \mathrm{ml}$. amphotericin B (FungizoneGIBCO).

The second culturette from each patient numbered 1 to 36 was cultured on:

(a) Two plates of 5 per cent. defibrinated sheep blood in blood agar base (Infusion Agar-BBL) with $250 \mu \mathrm{g}$./ ml. amphotericin B (Fungizone-GIBCO);

(b) Chocolate agar prepared from heated blood agar with Supplement A and B (Difco);

(c) Thayer-Martin prepared as the chocolate agar with the addition of vancomycin $30 \mu \mathrm{g} . / \mathrm{ml}$., colistin 75 $\mu \mathrm{g} . / \mathrm{ml}$., and nystatin 125 units $/ \mathrm{ml}$. (V-C-N InhibitorBBL);

(d) Thioglycollate broth (Difco) without methylene blue or resazurin indicators for detection of anaerobic organisms.

The second culturette from each of the patients numbered 37 to 80 was inoculated on the same media, except that Trypticase Soy Agar (BBL) was used for the blood agar base.

Serratia Media, Mannitol Salt Agar, and Eosin-Methylene-Blue media were incubated aerobically at $37^{\circ} \mathrm{C}$. Sabouraud Dextrose Agar was incubated initially for 48 hrs at $37^{\circ} \mathrm{C}$., then at room temperature for an additional 5 days. One of the blood agar plates from each specimen was incubated at $37^{\circ} \mathrm{C}$. in an anaerobic jar (Torsal Model AJ-2, Torsion Balance Co., Clifton, N.J.). All other plates were incubated at $37^{\circ} \mathrm{C}$. in a candlestick jar. If higher concentrations of $\mathrm{CO}_{2}$ were required on secondary cultures, a $\mathrm{CO}_{2}$ incubator (National Model 3418, National Appliance Co., Portland, Ore.) was used.

\section{WET MOUNTS}

The transport media remaining in the culturettes after the swabs had been removed were then used to make the wet mounts. These were examined microscopically for the presence of trichomonads, yeast, pus cells, and epithelial cells.

\section{GRAM STAINS}

Slides were Gram stained and at least ten $\frac{1}{12}$ th oil immersion fields were examined to determine the preponderant organism.

\section{BIOCHEMICAL METHODS}

The bacterial flora was determined by standard methods (Soc. Amer. Bacteriol., 1957; Edwards and Ewing, 1962; 
Bailey and Scott, 1970). Periodic confirmatory tests of organisms isolated were performed by the Illinois State Board of Health Laboratories.

CANDIDA ALBICANS was identified by its ability to produce pseudogerm tubes in serum at $37^{\circ} \mathrm{C}$. (Taschdjian, Burchall, and Kozinn, 1960), by its production of chlamydospores, by sugar fermentation, and by assimilation tests on appropriate media (Lodder and Kreger-van Rij, 1952).

\section{ANTIBIOTIC SENSITIVITIES}

A standardized inoculum of pure culture of the various organisms was streaked on blood agar plates. The following discs were applied: tetracycline hydrochloride -30 $\mu \mathrm{g} .$, novobiocin $-30 \mu \mathrm{g}$., lincomycin hydrochloride $-2 \mu \mathrm{g}$. (Upjohn Co.), bacitracin -2 units, sulphasoxazole -300 $\mu g$., sodium-cephalothin - $30 \mu \mathrm{g}$., neomycin - $30 \mu \mathrm{g}$., chlortetracycline $-30 \mu \mathrm{g}$., and colistin $-10 \mu \mathrm{g}$. (Lederle Laboratories). The selection of these antibiotics was made on an empirical basis.

\section{Results}

WET MOUNTS

The incidence of Trichomonas vaginalis was 9 per cent. Of the seven patients harbouring this organism, five, of whom three were pregnant, had concomitant yeast growth.

\section{GRAM STAINS}

The preponderant morphological form in each of the eighty smears was classified and the percentage of each of these forms is reported in Table I.

TABLE I Classification of findings in

Gram-stained smears in eighty cases Morphology of preponderating organisms *

\begin{tabular}{|c|c|}
\hline Morphology & Percentage of total \\
\hline $\begin{array}{l}\text { Gram-positive long thin rods like Lactobacillus } \\
\text { Gram-negative short thin pleomorphic rodst } \\
\text { Diphtheroids (Corynebacterium) } \\
\text { Gram-positive cocci } \\
\text { Gram-negative intracellular diplococci like } \\
\text { Neisseria gonorrhoeae } \\
\text { Gram-negative large thick rods }\end{array}$ & $\begin{array}{l}30 \\
25 \\
20 \\
20 \\
2 \cdot 5 \\
2 \cdot 5\end{array}$ \\
\hline
\end{tabular}

\section{MICROBIAL CULTURES}

Table II lists each patient and the organisms isolated from her cervical os. The number of patients having a specific kind of organism and the frequency of such occurrence in the patient group is reported in Table III.

\section{YEASTS}

Of the women studied, 54 per cent. had one or more types of yeast isolated from the external os of the
TABLE III Number of patients with specific organism; frequency of occurrence among total patients

\begin{tabular}{|c|c|c|}
\hline Organisms* & No. & Per cent. \\
\hline Micrococcaceae† & 62 & 78 \\
\hline Diphtheroids & 54 & 68 \\
\hline Lactobacillus & 48 & 60 \\
\hline Total yeasts $\ddagger$ & 43 & 54 \\
\hline Other yeast & 25 & 31 \\
\hline Candida albicans & 21 & 27 \\
\hline Total large Gram-negative rods $₫$ & 32 & 40 \\
\hline Escherichia coli & 18 & 22 \\
\hline Enterobacter & 16 & 20 \\
\hline Proteus & 9 & 11 \\
\hline Pseudomonas and Pseudomonads & 3 & 4 \\
\hline Gamma nonhaemolytic Streptococcus & 20 & 25 \\
\hline Beta-haemolytic Streptococcus & 10 & 13 \\
\hline Trichomonas vaginalis & 7 & 9 \\
\hline Corynebacterium vaginalis & 7 & 9 \\
\hline Alpha-haemolytic Streptococci & 5 & 6 \\
\hline Neisseria gonorrhoeae $\|$ & 2 & 2 \\
\hline Staphylococcus aureus & 1 & 1 \\
\hline
\end{tabular}

*Listed in order of descending frequency of growth

†Excluding Staphylococcus aureus

$¥$ Some patients grew more than one type of yeast

\$Some patients grew more than one type of large Gram-negative rod

\|Seen in smears but cultures negative

cervix. Almost half of the cultures were of Candida albicans. Five cultures grouped as 'other yeasts' were further identified as Candida krusei, Candida species, and Torulopsis glabrata (three cultures). Two women harboured Candida albicans and Candida species; Candida albicans and Torulopsis glabrata were isolated from a third patient. In the cases of nine patients, yeast was recovered only on subculture from thioglycollate broth.

\section{Bacteria}

Lactobacillus was harboured by 48 patients (60 per cent.). This organism was isolated in 70 per cent. of the 43 patients with yeast growth, but in the remaining 37 patients without yeast growth the incidence of Lactobacillus was 49 per cent. In all instances, growth was enhanced by an anaerobic environment. The difference in the proportions of patients who did and did not have concomitant yeast growth is not statistically significant $\left(x^{2}=3.39 ; P>0.05\right)$.

\section{Corynebacteria}

The incidence of cultured diphtheroids in this survey was 68 per cent. The four distinct colonial types observed on blood agar plates after 48 hours' incubation are listed in Table IV. The colony most frequently isolated corresponded with a colony of Corynebacterium previously described by Brzin (1969). More than one colonial type of diphtheroid appeared in cultures of ten patients. Although the incidence of an organism resembling Corynebacterium vaginale (Dunkelberg, Skaggs, and Kellogg, 1970a) 
TABLE II Patient data; organisms isolated from each cervical os

\begin{tabular}{|c|c|c|}
\hline Patient no. & Physical status & Organisms grown $\left({ }^{\star}\right.$ Key) \\
\hline $\begin{array}{l}1 \\
2 \\
3 \\
4 \\
5 \\
6 \\
7 \\
8 \\
9 \\
10 \\
11 \\
12 \\
13 \\
14 \\
15 \\
16 \\
17 \\
18 \\
19 \\
20 \\
21 \\
22 \\
23 \\
24 \\
25 \\
26\end{array}$ & Pregnant & $\begin{array}{l}1,2,3,7,13 \\
2,3,7 \\
3,6,12,13 \\
1,3,5,13,14 \\
1,2,3,13 \\
1,2,3 \\
1,2,3,13 \\
2,3,7,13 \\
2,8,10,12,15 \\
1,3,5,12 \\
2,3,7,9,16 \\
1,7,12 \\
1,3,13 \\
1,3,9,12 \\
2.3,12.13 \\
2,3,10,13,15 \\
3,7 \\
1,2,3,9,10 \\
1,3,6.9,12.13 \\
13,15 \\
1,3,12 \\
1,2,3,6,12 \\
1,2,3,12 \\
1,2,3 \\
2.3,8,10,12 \\
3,5,6,16\end{array}$ \\
\hline $\begin{array}{l}27 \\
23 \\
29 \\
30 \\
31 \\
32 \\
33 \\
31 \\
35 \\
36 \\
37 \\
38 \\
39\end{array}$ & Postpartum & $\begin{array}{l}2,3,13 \\
3 \\
1,2,7,13 \\
1,7,8 \\
2,6,11 \\
2,7,15 \\
1,2,3.13 \\
1,2,3.10,13 \\
3,8,11.16 \\
1,2,3.7,8,10 \\
2,3,8 \\
1,2,3,12 \\
1,3,5,8,10\end{array}$ \\
\hline $\begin{array}{l}40 \\
41 \\
42 \\
43 \\
44 \\
45 \\
46 \\
47\end{array}$ & Amenorrhoea & $\begin{array}{l}2,3,7,10 \\
1,2,13,15 \\
3,7,10,12 \\
1,3,6,13 \\
1,2,3,6,7,12 \\
2.3,12,15,16 \\
1,3,10 \\
1,2,3,13\end{array}$ \\
\hline $\begin{array}{l}48 \\
49 \\
50 \\
51 \\
52 \\
53 \\
54 \\
55 \\
56 \\
57 \\
58 \\
59 \\
60 \\
61 \\
62 \\
63 \\
64 \\
65 \\
66 \\
67 \\
68\end{array}$ & Normal & $\begin{array}{l}1,2,3,8 \\
3,7 \\
1,2,3 \\
1,2,38 \\
1,2.3,6,12 \\
1,2,9 \\
3 \\
2,8,9 \\
2,6,11 \\
1,2,3,13,15 \\
3,7,8,9,10,12 \\
1,2,3,8.10,13 \\
2,6,10,12 \\
1,3,8,9,10 \\
1,2 \\
1,3,7,13 \\
1,3,7,8 \\
1,3,5,8,9,13 \\
3 \\
1,2,3 \\
2,7,8\end{array}$ \\
\hline
\end{tabular}

\begin{tabular}{|c|c|c|}
\hline Patient no. & Physical status & Organisms grown ( ${ }^{\star}$ Key) \\
\hline $\begin{array}{l}69 \\
70 \\
71 \\
72 \\
73 \\
74 \\
75 \\
76 \\
77 \\
78 \\
79 \\
80\end{array}$ & Contraception & $\begin{array}{l}2,3,14 \\
2 \\
1,2,3,12 \\
1,2,3,12 \\
1,2,13 \\
2,3,7 \\
1,2,3,16 \\
2,3,8,13 \\
1,2,3,8,10,13,16 \\
1,2,13,16 \\
1,2 ; \\
2,3,4,10,12\end{array}$ \\
\hline
\end{tabular}

Growth ( $\star$ Key):

$1=$ Lactobacillus

$2=$ Diphtheroids

3 = Micrococcaceae (excluding Staphylococcus aureus)

$4=$ Staphylococcus aureus

5 = Alpha-haemolytic

Streptococcus

6 = Beta-haemolytic Streptococcus

7 = Gamma-haemolytic

Streptococcus

$8=$ Escherichia coli

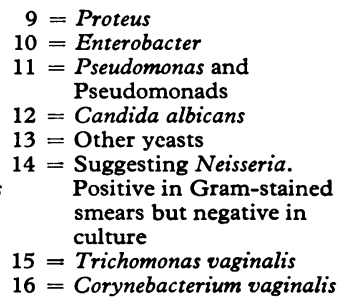

on direct smear was 25 per cent., this bacterium was cultured from only seven patients. From these women, a pinpoint, nonhaemolytic, catalase-negative colony with Gram-negative coryneform structure was isolated in a mixed flora. The organism grew well on chocolate agar and minimally on sheep blood agar. The wet mounts from two patients in this group showed numerous epithelial 'clue' cells (Gardner and Dukes, 1955). A Gram-stained smear from one patient in this group revealed numerous polymorphonuclear leucocytes filled with small Gram-negative rods.

TABLE IV Colonial types of diphtheroids cultured on blood agar

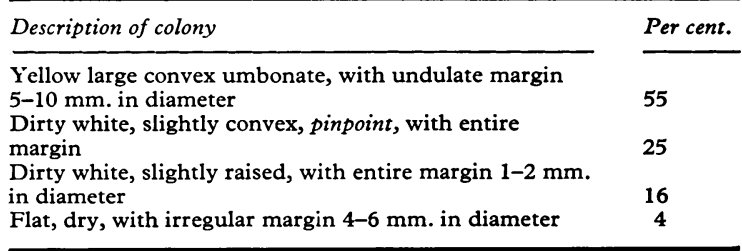

Enterobacteriaceae and Pseudomonadaceae

Escherichia coli, Enterobacter, Proteus, or Pseudomonas/Pseudomonads were isolated from the external os of each of 32 women ( 40 per cent.). More than one Gram-negative rod was isolated from each of twelve of these patients. Of these concomitant growths, Escherichia coli and Enterobacter were most frequent. Of the eighteen cultures positive for Escherichia coli, only two were in pregnant patients in the Prenatal 
Clinic. All the Proteus micro-organisms isolated were further identified as Proteus mirabilis.

\section{Micrococcaceae (excluding Staphylococcus aureus)}

The preponderant organism in this group was a Gram-positive coccus in clusters. The colony was white, convex, coagulase-negative, and catalasepositive. Two cultures of an organism resembling a Sarcina species gave round, yellow, convex colonies which formed tetrads in broth culture.

\section{Streptococci}

The beta-haemolytic streptococcal colonies on blood agar were grey, mucoid, slightly translucent, and about 2 to $3 \mathrm{~mm}$. in diameter. All cultures of this organism grew in SF broth but did not change the indicator. These organisms failed to grow on EMB agar and were resistant to bacitracin and all other antibiotics tested. These observations are consistent with those for Lancefield Group B (Braunstein, Tucker, and Gibson, 1969). Two cultures of the gamma nonhaemolytic streptococci were further identified as Streptococcus faecalis, variety liquefaciens.

\section{Fusiforms}

Fusiform rods were identified on the Gram-stained smear from one patient (Table I, footnote); similar forms were observed in four thioglycollate broths after 72 hours' incubation. Attempts to subculture this organism failed. No other anaerobic organisms were cultured.

\section{Neisseria gonorrhoeae}

This organism, identified in Gram-stained smears in two cases, was not recovered on Thayer-Martin selective media.

\section{Serratia}

Positive cultures were not obtained.

\section{Discussion}

The external os of the cervix harbours a number of micro-organisms, most of which have been identified in other areas of the female urogenital tract. The incidence of isolation varies from study to study, possibly because of differences in the patient populations surveyed, and the techniques used to isolate and characterize the organisms.

Lactobacillus, long regarded as the preponderant organism in cultures of vaginal secretions from premenopausal women, has been less prevalent in recent years (Dunkelberg, Hefner, Patow, Wyman, and Orup, 1962; Redmond and Kotcher, 1963; Morris and Morris, 1967). In our study Lactobacillus was isolated from the external os in 60 per cent. of cases, but rarely predominated in culture.
Our finding that 54 per cent. of the eighty women harboured yeasts in the cervix (almost half of these being Candida albicans) is far higher than the incidence of 10 per cent. positive results from the cervices of 59 prostitutes examined on the island of Taiwan (Chiang and others, 1968). Eighteen of the 26 pregnant patients in our survey had yeasts in the cervix compared with 25 of the 54 nonpregnant patients; the difference ( 69 and 46 per cent.) is statistically significant $(P=<0.05)$. This finding corresponds with the increased incidence of yeasts in the vagina in pregnant women reported by Krupp and St. Romain (1960) and Pedersen (1969). Reports on the incidence of yeasts in the vagina in nonpregnant women have not been in agreement. Yeasts were found in 17 per cent. of a group of 291 patients attending a Family Planning Clinic (Morris, 1969), but in another study of 88 women hospitalized for abdominal surgical procedures, vaginal cultures yielded only one instance of isolation of Candida albicans (Bonnar, Bruce, and Low, 1969).

One explanation of the high incidence of yeasts may be the type of epithelium present in the area cultured. In rodents, indigenous yeast growth is favoured on secreting epithelium of the stomach whereas Lactobacillus grows better on nonsecreting epithelium (Savage, 1969). A similar situation may exist in the mucus-secreting columnar epithelium oi the human cervix and in the nonsecreting stratified squamous epithelium of the vagina. The mucosa of the cervix contains numerous large glands which branch extensively and are lined with tall, mucussecreting columnar cells. Such mucus may have antibacterial activity in some women (Kurochkin, Mesniankina, and Iasenskaia, 1969). This concept had previously been applied to vaginal secretions but not specifically to the cervix. In one reported study (Wilson and Miles, 1964), swabs were taken near the 'transitional zone' between the secreting epithelium of the cervix and the non-secreting epithelium of the vagina. In pregnant women and those recently postpartum, this 'transitional zone' may be situated far out on the portio vaginalis of the cervix. In nonpregnant women this area is generally located within the endocervix. These anatomical factors may be related to a high incidence of yeasts in pregnant patients and lower incidences in the other groups.

Three different types of Corynebacteria were observed in our study:

(1) A group of unclassified Corynebacteria (diphtheroids) were cultured from 68 per cent. of our patients. In studies of the vaginal flora, diphtheroids were either not reported or were noted at an incidence as low as 13 per cent. (Dunkelberg and others, 1962); 
in another report, they were cultured from 75 per cent. of the patients (Lapage, 1961).

(2) Corynebacterium vaginale. Whether or not this organism is part of the normal flora of the external cervical os has not been decided. Delaha, Curtin, Stevens, and Osborne (1964) believed that this organism was part of the normal vaginal flora. On the other hand, it has been suggested that Corynebacterium vaginale infection seems to qualify as a sexually transmitted disorder (Leopold, 1953), though it is of low virulence (Criswell, Ladwig, Gardner, and Dukes, 1969). In our study, we found an organism resembling Corynebacterium vaginale in Gram-stained smears from 25 per cent. of cases, but it was cultured from only 9 per cent. Neither the positive smears nor the culture results could be correlated with clinical symptoms. This 9 per cent. incidence by culture is much less than that found by Dunkelberg and co-workers, who studied the cervical os and posterior vagina of patients seen in a Venereal Diseases Clinic (Dunkelberg, Skaggs, Kellogg, and Domescik, 1970b). Our failure to culture the organism in more cases may be due to the enriched media used (Redmond and Kotcher, 1963; Dunkelberg and McVeigh, 1969). On the other hand, this bacterium might not be as prevalent in the cervix, since its main source of energy is glycogen (Edmunds, 1962), in which the cervical epithelium is lacking.

(3) In the Gram-stained smears, dispersed between the Gram-positive cocci, were small, lightly staining Gram-negative coryneform rods. All attempts at isolation failed. These results suggest the strain of Corynebacterium vaginalis (Haemophilus) described by Lapage (1961).

We had expected to culture gonococci in a number of cases because prenatal screening using ThayerMartin media had been reported to reveal gonococcal infection in 5 to 6 per cent. in such patients (Zackler, Brolnitsky, and Orbach, 1970). Cervical culturettes from the two cases in our study associated with suspicious findings in Gram stained smears were placed on Thayer-Martin media with infusion agar as a base, but Neisseria gonorrhoeae was cultured from neither.

A review of reports concerning the genus Serratia showed that, since 1952, Serratia marcescens had caused a variety of human infections, especially those acquired in hospitals (Amoury, Bowman, and Malm, 1966; Sanders, Luby, Johanson, Barnett, and Sanford 1970; Williams and Johnson, 1970). We had hoped to learn whether this organism was present in the external cervical os, and might be a possible source of infection: Serratia was not isolated.
Streptococci have been incriminated as causative agents for a number of gynaecological infections. Gamma nonhaemolytic streptococci were found in 25 per cent. of the patients; beta-haemolytic streptococci in 13 per cent., and alpha-haemolytic streptococci in 6 per cent.) (Table III). No anaerobic streptococci were cultured. These findings suggest that such organisms may have diminished clinical significance in the aetiology of postpartum and postabortal sepsis.

The finding of large Gram-negative rods in the cervix in 40 per cent. of cases suggests that these organisms may have increased clinical significance in pelvic inflammatory disease and postpartum and postabortal sepsis. This observation also confirms the impression that the cervix is the portal of entry for the Gram-negative organism (Lodder and Kregervan Rij, 1952; Galinski and others, 1969).

Of equal clinical importance is the fact that $E$. coli from both cervical and urinary cultures profoundly depress the motility and viability of human spermatozoa in vitro (Teague, Boyarsky, and Glenn, 1971). Similarly, it has been shown that $E$. coli infections in man decrease sperm motility (Schirren and Zander, 1966). These findings appear to be related to the observation of Matthews and Buxton (1951) that certain bacteria cultured from the cervix were spermicidal.

In spite of intensive efforts to recover anaerobic organisms from these patients, no anaerobes were cultured. However, fusiform rods were seen on Gram-stained smears from four thioglycollate broths. We had expected to recover a number of anaerobic organisms, and we have no explanation for this discrepancy.

Our results indicate a possible difference between the microbial flora of the external os and that of the vagina. If this is a real difference, it is not a qualitative one, as all the organisms present on the external os have been observed in the vagina. The difference is probably one of distribution, so that the organisms preponderant on the external os differ from those preponderant in the vagina. Competition for epithelial surfaces (Savage, 1969), subtle differences in $p \mathrm{H}$ (Cohen, 1969), cellular glycogen content (Edmunds, 1962), and biochemical properties of cervical mucus (Kurochkin and others, 1969) may all play a part in determining the number, type, and location of microorganisms in the female genital tract.

\section{Summary}

Published information regarding microbial flora of the cervix is scanty. A study of the external cervical os in a group of eighty premenopausal women examined during a 3-month period in 1970 disclosed 
a mixed microbial flora in 95 per cent. of the cultures. Yeast were present in 54 per cent. of all patients and in 69 per cent. of the pregnant patients. Although Lactobacillus was isolated from 60 per cent. of the total number of women, it was rarely preponderant in culture. Diphtheroids (Corynebacterium) grew in cultures from 68 per cent. of the women. Neisseria gonorrhoeae were not cultured, although, in two cases, appearances in the Gram-stained direct smears were suggestive. Serratia were not isolated from the external os in any case. One or more Gram-negative organisms were isolated in cultures from 40 per cent. of the women studied. Streptococci, often identified in postpartum and postabortal sepsis, were isolated at rates suggesting diminished clinical significance. Our results indicate a possible difference between the distribution of the microbial flora of the external os and that of the vagina.

\section{References}

Amoury, R. A., Bowman, F. O., and MaLM, J. R. (1966) F. thorac. cardiovasc. Surg., 51, 36

BaIley, W. R., and Scott, E. G. (1970) 'Diagnostic Micro-Biology', 3rd ed. Mosby, St. Louis

Bonnar, J., BruCE, L. G., and Low R. A. (1969) $\mathcal{f}$. Obstet. Gynaec. Brit. Cwlth, 76, 850

Braunstein, H., Tucker, E. B., and Gibson, B. C. (1969) Amer. F. clin. Path., 51, 207

Brzin, B. (1969) Zbl. Bakt., Abt. 1 (Originale), 210, 202

Chiang, W. T., Alexander E. R., Wei, P. Y., and FRESH, J. W. (1968) Amer. F. Obstet. Gynec., 100, 422

CoHEN, L. (1969) Brit. F. vener. Dis., 45, 241

Criswell, B. S., LAdWig, C. L., GARDNER, H. L., and Dukes, E. D. (1969) Obstet. and Gynec., 33, 195

Delaha, E. C., Curtin, J. A., Stevens, G., and Osborne, H. J. (1964) Amer. F. Obstet Gynec., 89, 996

Dunkelberg, W. E., Hefner, J. D., Patow, W. E., WyMAN, F. J., and ORUP, H. I. (1962) Obstet. and Gynec., 20, 629

and McVigr, I. (1969) Antonie van Leeuwenhoek, 35, 129

- Skaggs, R., and Kellogg, D. S. (1970a) Amer. $\mathcal{F}$. clin. Path., 53, 370

,,--- , and Domescik, G. K. (1970b) Brit. f. vener. Dis., 46, 187

Edmunds P. N. (1962) f. Path. Bact., 83, 411

EDWARDS, P. R., and EwING, W. H. (1962) 'Identification of Enterobacteriaceae', 2nd ed. Burgess, Minneapolis

GALINSKI, J., MIERZEJEWSKI, W., and EMERICH, J. (1969) Ginek. Pol., 40, 1141

GaRdNeR, H. L., and Dukes, C. D. (1955) Amer. F. Obstet. Gynec., 69, 962

Goldin, M., ShafFer, J. G., and BRown, E. (1969) Bact. Proc., p. 96 (M188)

KRUPP, P. J., and St. Romain, M. J. (1960) F. La med. Soc., 112, 176

KuROCHKIN, B. I., MESNiankina, N. V., and IASENSKaiA, V. A. (1969) Antibiot. Mosk., 14, 929
LAPAGE, S. P. (1961) Acta path. microbiol. scand., 52, 34

LEOPOLd, S. (1953) U.S. armed Forces med., f., 4, 263

LIKAR, M., and MrŠEvić, S. (1967) Med. Przegl., 20, 471

LODDER, J., and KREGER-VAN RIJ, N. J. W. (1952) 'The Yeasts'. Interscience, New York

Matthews, C. S., and Buxton, C. L. (1951) Fertil. Steril., 2, 45

MORRIs, C. A. (1969) f. clin. Path., 22, 488

- and MorRIS, D. F. (1967) Ibid., 20, 636

Pedersen, G. T. (1969) Dan. med. Bull., 16, 207

REDMond, D. L., and KotCher, E. (1963) F. gen. Microbiol., 33, 89

SANDERS, C. V., JR., Luby, J. P., Johanson, W. G., JR., BarnetT, J. A., and SANFord, J. P. (1970) Ann. intern. Med., 73, 15

SAVAGE, D. C. (1969) f. Bact., 98, 1278

SCHIRREN, C., and ZANDER, H. A. (1966) Med. Welt, 1, 45

Soc. Amer. Bacteriologists (1957) 'Manual of Microbiological Methods'. McGraw-Hill, New York

Taschdjian, C. L., BuRchall, J. J., and KozinN, P. J. (1960) Amer. F. Dis. Child., 99, 212

Teague, N. S., Boyarsky, S., and GlenN, J. F. (1971) Fertil. Steril., 22, 281

Williams, J. C., JR., and Johnson, J. E. (1970) Arch. intern. Med., 125, 1038

WILson, G. S., and Miles, A. A. (1964) 'Topley and Wilson's Principles of Bacteriology and Immunity', 5th ed. Arnold, London

ZACKLER, J., BrolNitsKy, O., and ORBACH, H. (1970) Publ. Hlth Rep. (Wash.), 85, 681

La flore microbienne de l'orifice externe du col utérin à la préménopause

SOMMAIRE

L'information publiée sur la flore microbienne du col est peu abondante. Une étude de l'orifice externe du col dans un groupe de 80 femmes pré-ménopausiques examinées pendant une période de 3 mois en 1970, révéla une flore microbienne mixte pour 95 pour cent des cultures. Des levures furent présentes chez 54 pour cent de l'ensemble des malades et chez 69 pour cent de celles en état de grossesse. Bien que Lactobacillus fut isolé chez 60 pour cent du total des femmes, il fut rarement prépondérent en culture. Les diphtéroïdes (Corynebacterium) poussèrent en culture chez 68 pour cent des femmes. Aucun Neisseria gonorrhoeae ne poussa, bien que dans deux cas l'aspect des étalements directs colorés au Gram fit penser à leur présence. Des Serratia ne furent isolés de l'orifice externe dans aucun cas. Un ou plusieurs organismes $\mathrm{Gram}$-négatif furent isolés par culture chez $\mathbf{4 0}$ pour cent des femmes étudiées. Streptococci, souvent identifiés dans le post-partum ou les infections post-abortum, furent isolés à des taux suggérant la diminution de leur signification clinique. Nos résultats indiquent une différence possible entre la distribution de la flore de l'orifice externe et de celle du vagin. 